\title{
Comparison of yields and physicochemical properties of lime juice with acetic acid and calcium chloride coagulated soybean curds
}

\author{
Obiegbuna James E. ${ }^{1,}$, Morah Grace N. ${ }^{2}$, Ishiwu Charles N. ${ }^{1}$ \\ ${ }^{1}$ Department of Food Science and Technology, Nnamdi Azikiwe University, Awka, Nigeria \\ ${ }^{2}$ Dept. of Hotel and Catering Management, Federal Polytechnic, Idah, Kogi State; Nigeria
}

Email address:

jamesobifst@yahoo.com (Obiegbuna J. E.)

\section{To cite this article:}

Obiegbuna James E., Morah Grace N., Ishiwu Charles N.. Comparison of Yields and Physicochemical Properties of Lime Juice with Acetic Acid and Calcium Chloride Coagulated Soybean Curds. Journal of Food and Nutrition Sciences. Vol. 2, No. 3, 2014 , pp. 58-62. doi: $10.11648 /$ j.jfns.20140203.12

\begin{abstract}
The yield, proximate composition and functional properties of soybean curd produced using lime juice as coagulant was compared with those produced using acetic acid and $\mathrm{CaCl}_{2}$. Curd was produced from soymilk using $0.5 \%$ of lime juice ( $6.32 \%$ citric acid). Guided by the titratable acidity of lime juice, curds were also produced using $0.5 \%$ of $6.32 \%$ solutions of acetic acid and $\mathrm{CaCl}_{2}$ in water, respectively. The lime juice produced significantly $(\mathrm{p}<0.05)$ lesser curd than acetic acid. The proximate analysis revealed that only the protein and carbohydrate contents of curds differed significantly $(\mathrm{p}<0.05)$. The lime juice-coagulated curd had the highest protein but lowest carbohydrate contents. Functionally, only protein solubility, emulsion activity and foaming capacity of the curds differed significantly $(p<0.05)$ with the lime juice coagulated curds having the highest values. Judging by the amount of protein precipitated and the functional properties, lime juice may have produced better curd than acetic acid and $\mathrm{CaCl}_{2}$. However, curds with higher protein content and better functional properties may be expected should acetic acid and $\mathrm{CaCl}_{2}$ be applied as pure liquid or solid as reported in the literatures; and local processors in Nigeria that use lime juice as coagulant must use higher volume of the juice to optimize the yield and quality of curd.
\end{abstract}

Keywords: Soybean Curd, Lime Juice, Calcium Chloride, Acetic Acid, Physicochemical Properties

\section{Introduction}

Soybean is the best source of vegetable protein for all including growing children and babies. The beans are generally not eaten in the fresh state but as processed product [1]. This is because, its nutritive value is improved by processing into product such as soymilk, soy flour, roasted soybean and curd [2]. Soymilk, a dairy milk substitute easily prepared from mature dry beans is fast becoming a household food in developing countries including Nigeria because of its diet improving capabilities [3]. Like animal milk, soymilk is used in the manufacture of other food products due to its functional properties and nutritive value. Despite its intrinsic beany flavor [4], it has gained wild acceptances. However, utilization is limited due to short shelf-life. Local processors of soymilk in Nigeria, rather than discarding the unsold milk at the end of the day due to lack of refrigeration facilities, coagulate it into curd using lime juice.

This coagulated product known as tofu, has found acceptances as a high protein food for human consumption [5] and has been used as a protein source in the orient for many centuries. Tofu or soybean curd is most important and valued soy food throughout the world especially in Eastern and South Eastern Asian countries due to their inexpensive and high quality protein [6]. It is cholesterol free and contains high quality protein that can be easily digested [7, 8]. It was suggested [9] that the incorporation of soybean curd into Western diets could be an important means of preventing and treating chronic disease such as cancer and cardiovascular disease as supported by epidemiological studies.

Coagulation is the most important step in soybean curd making process [9]. Various coagulants used in curdling or coagulating soymilk have been listed [5]. The most commonly used coagulants are calcium and magnesium salts and glucono- $\delta$-lactone depending on tofu type [10]. Usually, 
$\mathrm{CaSO}_{4}$ and glucono- $\delta$-lactone are used more than other coagulants on the industrial scale for tofu making [11, 12].

Factors such as variety of soybean $[13,14]$, processing method [15] and type and concentration of coagulant [11, $13,14]$ have been reported to influence the yield, quality and texture of tofu. It has been demonstrated $[5,16]$ that the rheological properties of winged bean and pea curds; and soybean curd were affected by the coagulant used in their preparations. Soybean varieties influenced the qualities of soymilk and also affected the functional properties of tofu powder [10]. It has also been reported [17] that coagulants influence the yield and micronutrients contents of tofu.

The effects of the coagulants on the functional properties of soybean curds have not or have rarely been investigated. The most common coagulant available to the local processor in Nigeria is lime juice. This research studies the yield, proximate composition and functional properties of soybean curd prepared using lime juice and compared it with those prepared with acetic acid and calcium chloride $\left(\mathrm{CaCl}_{2}\right)$.

\section{Materials and Method}

\subsection{Sample Preparation}

Soybean (Glycine max) seeds were purchased from Idah Main Market in Kogi State of Nigeria. The seeds were sorted and soaked in water (1:5 soybean: water) overnight at room temperature $\left(30 \pm 1^{0} \mathrm{C}\right)$, dehulled and washed. The swollen hydrated cotyledons were then blended in a blender (type HR 1731, Philips, Brazil) with tap water $\left(100^{\circ} \mathrm{C}\right)$ at water: bean ratio of $6: 1$ for $5 \mathrm{~min}$. The slurry was strained through eight layers of cheese cloth and the filterate boiled for $15 \mathrm{~min}$ and then cooled to room temperature $\left(30 \pm 1^{0} \mathrm{C}\right)$. The milk was then divided into three equal parts. A $3 \%$ ground Calotropis proceran leaves was wrapped in cheese cloth and immersed for $5 \mathrm{~min}$ in each portion. Subsequently, $0.5 \%(\mathrm{v} / \mathrm{v})$ of lime juice (characteristics presented in Table 1) was added to the first portion. Following the titratable acidity of $6.32 \%$ (expressed as citric acid) of lime juice (Table 1), $0.5 \%$ of $6.32 \%$ solutions of acetic acid and calcium chloride $\left(\mathrm{CaCl}_{2}\right)$ in water were added to the second and third portions, respectively. The mixtures were then poured over cheese cloth and the liquid pressed out. The semi-solid curds were sun-dried for 2 days and milled into powder.

\subsection{Characterization of Lime Juice}

The titratable acidity of clarified lime juice was determined by titrating $10 \mathrm{ml}$ of the juice with $0.1 \mathrm{~N} \mathrm{NaOH}$ solution, using a phenolphthalein as indicator, to a pink colour end point. Total soluble solids and refractive index of the unclarified lime juice were estimated using Abbe refractometer. A total solid was determined [18] by oven drying $10 \mathrm{ml}$ of unclarified lime juice. The density of unclarified lime juice was determined using specific gravity bottle. A dry empty $25 \mathrm{~cm}^{3}$ specific gravity bottle was weighed with its lid. The bottle was filled with lime juice and weighed again. The ratio of the weight of the lime juice to its volume was expressed as the density.

\subsection{Curds Yield Determination}

The dried weight of the curds before milling was expressed as the percentage of the volume of the soymilk coagulated. This was referred to as the yield.

$$
\text { Yield }(\% \mathrm{w} / \mathrm{v})=\frac{\text { Soybean curd }(\mathrm{g})}{\text { Soymilk }(\mathrm{ml})} \times 100
$$

\subsection{Proximate Analysis}

The crude protein $(\mathrm{N} \times 6.25)$, fat, ash, and moisture contents of the curds were determined by the AOAC methods [18]. Carbohydrate content was estimated by difference.

\subsection{Functional Properties Determinations}

Protein solubility was determined on $1 \% \quad(\mathrm{w} / \mathrm{v})$ suspension of the curds. The suspensions of the curds were adjusted to neutral $\mathrm{pH}$ with $1 \mathrm{~N} \mathrm{NaOH}$ while stirred constantly for $20 \mathrm{~min}$ and centrifuged (Shermond, England) (set at mark 5) for $10 \min \left(30 \pm 1^{0} \mathrm{C}\right)$. The supernatant was analyzed for protein ( $\mathrm{N} \times 6.25)$ using microKjeldahl method [18]. Water and oil absorption capacities [19] and emulsion activity [20] were determined. The swelling capacity was estimated [21], except that differences in volume rather than weight was employed. Foam capacity was determined following a description [22]. All analyses were carried out in triplicate on the pooled curd samples of duplicate productions.

\subsection{Statistical Analysis}

Data were subjected to two-way analysis of variance (ANOVA) and significant means discriminated using Turkey's test [2].

Table 1. Characteristic of lime juice used in the soybean curd production

\begin{tabular}{ll}
\hline Characteristics & Value \\
\hline Total solids $(\%)$ & 9.61 \\
Total soluble solids $(\%)$ & 5.0 \\
Refractive index & 1.34 \\
Titratable acidity (\% citric acid) & 6.32 \\
Density $\left(\mathrm{g} / \mathrm{cm}^{3}\right)$ & 1.031 \\
\hline
\end{tabular}

\section{Results and Discussion}

\subsection{Soybean Curd Yield}

The yields of the soybean curds as influenced by coagulants are presented in Table 2. Lime juice produced significantly $(p<0.05)$ lesser curd than acetic acid. A soybean curd yield of $39.80 \%$ (dry basis) was observed [16] using $0.54 \% \mathrm{CaSO}_{4}$. Ranges of $58.69 \%$ for tofu coagulated with $\mathrm{CaSO}_{4}$ to $68.15 \%$ for tofu coagulated with $\mathrm{MgCl}_{2}$ were reported [17]. Also yields of $3.13 \mathrm{~kg} / \mathrm{kg}$ (moisture 
content $86.75 \%$ ) and $2.19 \mathrm{~kg} / \mathrm{kg}$ (moisture content $85.98 \%$ ) were observed [14] for fresh curds coagulated with $\mathrm{CaSO}_{4}$ and Withania, respectively. These researchers expressed the yield as percentage of the dry soybean rather than that of the soymilk coagulated, which was used in this work. For effective comparison, this work also used $0.5 \%$ of $6.32 \%$ solution of acetic acid and $\mathrm{CaCl}_{2}$ as the lime juice contained $6.32 \%$ citric acid. Hence, low coagulant concentrations may be the cause of lower yields observed in this work.

\subsection{Proximate Composition}

The proximate composition of the dried soybean curd, presented in Table 2, revealed that only protein and carbohydrate contents were significantly $(p<0.05)$ affected by the coagulants used. The protein content of the lime juice coagulated curd was significantly $(p<0.05)$ higher than acetic acid and $\mathrm{CaCl}_{2}$ coagulated curds. This may be an indication that lime juice has greater ability to precipitate protein than acetic acid and $\mathrm{CaCl}_{2}$. It was reported [5] that there were differences in the ability of various coagulants to precipitate winged been protein. They suggested that $\mathrm{CaSO}_{4}$ is the best coagulant. Calcium acetate and $\mathrm{CaCl}_{2}$ has been suggested [24] as good precipitant in favour of $\mathrm{CaSO}_{4}$ while preference for the use of $\mathrm{MgSO}_{4}$ over $\mathrm{CaCl}_{2}$ and vinegar has been reported [25]. It has also been reported [17] that coagulant modulated the percent yield, nutrients and antinutrients. The carbohydrate content of $\mathrm{CaCl}_{2}$ coagulated soybean curd was higher $(\mathrm{p}<0.05)$ than that of acetic acid coagulated curd which in turn had significantly higher $(\mathrm{p}<0.05)$ carbohydrate than lime juice coagulated curd Table 2. Carbohydrate content was estimated by difference. Therefore, the lower $(p<0.05)$ carbohydrate content of lime juice coagulated curd may be related to the higher $(\mathrm{p}<0.05)$ protein content. Also the significant difference $(\mathrm{p}<0.05)$ existing between the carbohydrate content of $\mathrm{CaCl}_{2}$ and acetic acid coagulated curd could be attributed to the resultant difference in protein, fat, ash and moisture contents which were higher in the acetic acid coagulated curd (Table 2). The carbohydrate content of $43.0-53.25 \%$ was far higher than the reported [17] $10.80-20.74 \%$ of six coagulant curds.

Table 2. Yield and proximate composition of dried soybean curds produced with lime juice, acetic acid and calcium chloride

\begin{tabular}{lcccc}
\hline & \multicolumn{3}{c}{ Soybean curds } & \\
\cline { 2 - 4 } Parameters & $\begin{array}{c}\text { Lime juice } \\
\text { coagulation }\end{array}$ & $\begin{array}{c}\text { Acetic acid } \\
\text { coagulation }\end{array}$ & $\begin{array}{c}\text { Calcium } \\
\text { chloride } \\
\text { coagulation }\end{array}$ & LSD \\
\hline Yield (\%) & $20.70^{\mathrm{a}}$ & $23.90^{\mathrm{b}}$ & $23.30^{\mathrm{ab}}$ & 2.99 \\
Moisture (\%) & $8.00^{\mathrm{a}}$ & $8.00^{\mathrm{a}}$ & $7.50^{\mathrm{a}}$ & 1.72 \\
Protein (\%) & $26.25^{\mathrm{a}}$ & $21.00^{\mathrm{a}}$ & $19.25^{\mathrm{a}}$ & 2.39 \\
Fat (\%) & $18.40^{\mathrm{a}}$ & $17.40^{\mathrm{a}}$ & $16.20^{\mathrm{a}}$ & 2.91 \\
Ash (\%) & $3.40^{\mathrm{a}}$ & $4.00^{\mathrm{a}}$ & $3.80^{\mathrm{a}}$ & 1.19 \\
Carbohydrate & $43.40^{\mathrm{a}}$ & $49.60^{\mathrm{b}}$ & $53.25^{\mathrm{c}}$ & 2.30 \\
\hline
\end{tabular}

Values with different superscript along the row are significantly different $(\mathrm{p}<0.05)$
Generally, the protein, fat and carbohydrate contents of the curds examined in this study ranged from 19.25 $26.25 \%, 16.20-18.40 \%$ and $43.95-53.25 \%$ respectively. Soybean curd produced using $\mathrm{CaSO}_{4}$ at $0.5 \%$ concentration contained $51.20 \%$ protein, $2.80 \%$ fat and $20.20 \%$ carbohydrate [5]. Also, using $0.54 \% \mathrm{CaSO}_{4}$ as coagulant, a protein, fat and nitrogen free extract contents (on moisture free basis) of $57.30,20.0$ and $8.10 \%$ respectively, was observed [16]. Although $\mathrm{CaSO}_{4}$ may be a better protein precipitant [5], lower protein content of the curds obtained in this study must have been caused by low level of the coagulants used. Guided by the titratable acidity of the lime juice (Table 1), acetic acid and $\mathrm{CaCl}_{2}$ solutions $(6.32 \%)$ were used at $0.5 \%$ level rather than as pure liquid or as solid salt granule, respectively. It was reported that pea protein and pea curd yield increased from 36.90 to $43.00 \%$ and 9.80 to $13.60 \%$, respectively, as the concentration of the coagulants increased from $0.15 \%$ to $0.54 \%$ [16]. They concluded that lower yields indicated incomplete coagulation.

Although the fat content of the soybean curds was not significantly $(\mathrm{p}<0.05)$ influenced by the coagulants used, they ran parallel to the protein content (Table 2). This may be indicating that during precipitation, proteins imbibe fats to themselves. The observed fat content was lower than $24.80 \%$ and $25.30 \%$ respectively, reported for soybean and winged bean curds [5] and 29\% for the soybean curd [16] but slightly higher than $7.87-15.39 \%$ reported for six coagulants [17]. The ash content of $3.40-4.00 \%$ observed in this work is lower than $5.80-8.80 \%$ [17].

\subsection{Functional Properties}

Among the functional properties examined (Table 3), only the protein solubility (PS), emulsion activity (EA), and foaming capacity (FC) of the curds were significantly $(\mathrm{p}<$ 0.05 ) affected by the coagulants used in the curd production. The PS ranged from 13.66 to $20.00 \%$. Lime juice coagulated curd had the highest value while $\mathrm{CaCl}_{2}$ coagulated curd had the lowest. PS profile is usually an index of protein functionality [26, 27], although protein hydrophobicity has been hypothesized to also play a crucial role $[28,29,30]$. The behaviour of proteins at the water/ oil interface is a function of emulsifying properties. The lime juice coagulated curd had the highest emulsion activity (EA) compared to the $\mathrm{CaCl}_{2}$ coagulated curd. The EA of the curd samples seemed to have direct relationship with the total protein content (Table 2) and protein solubility (Table 3). Hydrophobicity rather than solubility has been hypothesized to play a crucial role in determining the functional properties of protein [28, 29, 30]. Also the emulsification of oil with protein can be explained using the concept of protein hydrophobicity [27]. Based on this, $\mathrm{CaCl}_{2}$ coagulated curd could have been expected to have higher EA since the decrease in protein solubility usually increases the hydrophobicity due to exposure of hydrophobic amino acid residues of the native protein [27]. However, considering the actual total soluble protein 
content of the curd relative to the total protein content, lime juice coagulated curd may have more insolubilized protein. Moreover, effective or surface hydrophobicity, rather than the hydrophobicity of unfolded protein (total hydrophobicity), has been related to emulsifying properties $[27,30]$. Soluble protein has the potential for surface denaturation to provide the required hydrophpbocity at the instance of emulsion formation. Greater surface hydrophobicity may be expected from a curd with higher soluble protein. It was reported [30] that the emulsifying properties were generally improved with increasing surface hydrophobicity values at solubility values above $30 \%$. A higher value of emulsion properties, attributable to increased hydrophobicity in heat treated soy protein has been observed [27].

Table 3. Functional properties of dried soybean curds produced using lime juice, acetic acid and $\mathrm{CaCl}_{2}$

\begin{tabular}{lcccc}
\hline & \multicolumn{3}{c}{ Soybean curds } & \\
\cline { 2 - 4 } Parameters & $\begin{array}{l}\text { Lime juice } \\
\text { coagulated }\end{array}$ & $\begin{array}{c}\text { Acetic acid } \\
\text { coagulated }\end{array}$ & $\begin{array}{c}\text { Calcium } \\
\text { chloride } \\
\text { coagulated }\end{array}$ & LSD \\
\hline Protein solubility (\%) & $20.00^{\mathrm{b}}$ & $15.48^{\mathrm{a}}$ & $13.66^{\mathrm{a}}$ & 3.34 \\
$\begin{array}{l}\text { Oil absorption capacity } \\
(\%)\end{array}$ & $55.71^{\mathrm{a}}$ & $56.13^{\mathrm{a}}$ & $57.03^{\mathrm{a}}$ & 2.64 \\
Water absorption & $116.53^{\mathrm{a}}$ & $113.67^{\mathrm{a}}$ & $114.21^{\mathrm{a}}$ & 5.25 \\
capacity (\%) & $32.49^{\mathrm{a}}$ & $32.44^{\mathrm{a}}$ & $33.06^{\mathrm{a}}$ & 1.09 \\
Swelling capacity (\%) & $43.03^{\mathrm{b}}$ & $35.00^{\mathrm{a}}$ & $33.71^{\mathrm{a}}$ & 5.35 \\
Emulsion activity (\%) & $6.18^{\mathrm{b}}$ & $3.82^{\mathrm{a}}$ & $4.00^{\mathrm{a}}$ & 0.77 \\
\hline Foaming capacity (\%) & & & & \\
\hline
\end{tabular}

Values with different superscripts along the row are significantly different $(\mathrm{p}<0.05)$

The foaming properties of the soybean curds are presented in Table 3. Like in EA, the lime juice coagulated curd had the highest $\mathrm{FC}$ value while the $\mathrm{CaCl}_{2}$ coagulated curd had the lowest. Important contribution of protein solubility to the foaming behaviour of protein has been reported [31, 32]. Similar explanation for emulsification can apply since foaming is also a phenomenom which occurs at the interface, which in this case is air/water instead of oil/water [32]. However, unlike in emulsion formation, foaming properties has been reported to depend on the total hydrophobicity rather than the surface hydrophobicity $[32,30]$. The generally low foaming capacity and loss of foam stability may be attributed to the presence of coagulated protein which has reduced film stability and life because of the reduced film strength [31].

The water absorption capacity (WAC) and oil absorption capacity (OAC) of the soybean curds are shown in Table 3. Though, the differences among the curds were not significant $(p>0.05)$, the lime juice coagulated curd with higher protein content (Table 2) and higher protein solubility (Table 3 ) had the lowest OAC and highest WAC. The major chemical component that affects OAC is protein which is composed of both hydrophilic and hydrophobic groups [33]. Non-polar amino acid side chains can form hydrophobic interactions with hydrocarbon chain of lipid. Being less soluble in $\mathrm{CaCl}_{2}$ and acetic acid coagulated curds than in lime juice coagulated curd, it is not surprising that $\mathrm{CaCl}_{2}$ and acetic acid coagulated curds had higher OAC.

The higher WAC of lime juice coagulated curd may be related to higher polar amino acid of the protein. The proteins, being higher $(p<0.05)$ in solubility may likely have more affinity for water molecules. The fact that significantly higher protein content (Table 2) and protein solubility (Table 3) gave/ produced insignificantly higher WAC may be attributed to lower carbohydrate content which is also a factor in water absorption. It has been reported [33] that proteins and carbohydrates are the major chemical constituents involved in WAC, since they contain hydrophilic parts such as polar or charged side chains. From Table 2, these constituents are inverse in contents. This may be implying that protein had likely influenced that WAC than carbohydrate.

\section{Conclusion}

Lime juice produced lesser curd with higher protein content and greater protein solubility than acetic acid and $\mathrm{CaCl}_{2}$ solutions $(6.32 \%)$. This may be suggesting that lime juice may be a better protein precipitant than acetic acid and $\mathrm{CaCl}_{2}$. The higher protein content and greater protein solubility have probably resulted to higher EA and FC which, though may be affected by other components of the curd, are protein related functional properties. Higher protein precipitation of the lime has likely led to lower carbohydrate content of the curd. Generally, the extremely higher carbohydrate and lower protein and fat contents of the curds than the literature reports may be attributed to the eventually low level of coagulants used since the later can affect the protein yield. Hence, much of the soymilk proteins may have been lost by the use of the lime juice or $6.32 \%$ solutions of acetic acid and $\mathrm{CaCl}_{2}$ at $0.5 \%$ concentration. The local processors of curds in Nigeria must use high percentage of lime juice to optimize curd production and quality from soymilk.

\section{References}

[1] Osho, S.M. (1989). Soybean processing for household use. In: N.B. Mba and D.O. Nnanyelugo, Food Crops Production, Utilization and Nutrition.Dotam Publ. Ltd, Ibadan, Nigeria, pp $68-79$.

[2] Cowman, J.C. and Wolf, W.J. (1977). Soybean. In: N.W. Desrosier (ed.), Elements of Food Technology. AVI Publication Co. Inc., Westport, Connecticut, pp 202-211.

[3] Okaka, J.C. (1997). Cereal and Legume Storage Technology. Data and Microsystem Publ., Enugu, Nigeria, pp 3 -44.

[4] Cheman, Y.B., Wei, L.S. and Nelson, A.I. (1989). Acid inactivation of soybean lipoxygenase with retention of protein solubility. J. Food Sci. 50: $963-969$.

[5] Sri Kantha, S., Hettiarachehy, N.S. and Erdman, J.W. (jr) (1983). Laboratory scale production of winged bean curd. J. Food Sci. 8: 41 - 444. 
[6] Birthal, P.S., Parthasarathy Rao, P., Nigam, S.N. Bantilan, C.S. and Bhagavatula, S. (2010). Groundnut and Soybean Economies in Asia: Fact,Trends and Outlook. ICRISAT

[7] Lei, D., Fadong, Q. and Tang, D. (2007). Research significance onlactic acid bacteria concentrated fermentation agent. Henam Animal Husbandry Vet Syn Ed. J., 28(2): 13

[8] Guan, L. (2009). Study on soybean curd yield produced by lactic acid bacteria fermenting soybean milk. Food Tech. J., 34(3): $36-41$.

[9] Jianming, W., Quiqian, L., Yiyun, W. and Xi, C. (2013). Research on soybean curd coagulated by lactic acid bacteria. Springerplus, 2: 250259.

[10] Panyathitipong, W. and Puechkamut, Y. (2008). Qualities of tofu powder as affected by soybean variety, coagulant and drying method. Kasetsart (Nat. Sci.), 42: 156- 162.

[11] Lim, B.T., DeMan, J.M., DeMan, L. and Buzzell, R.I. (2006). Yield and quality of tofu as affected by soybean and soymilk characteristics. Calcium sulphate coagulant. J. Food Sci. 55: $1088-1092$.

[12] Tsai, S.I., Lan, C.Y., Kao, C.S. and Chen, S.C. (2006). Studies on the yield and quality characteristics of tofu. J. Food Sci. 46: 1734 -1737.

[13] Shen, C.F., Man, L., Buzzell, R.I. and DeMan, J.M. (2006). Yield and quality of tofu as affected by soybean and soymilk characteristics: glucono-delt-lactone coagulant. J. Food Sci. 56: $109-112$

[14] Sarani, R., Mohtadinia, J. and Jafarabadi, M.A. (2014). The effect of Withania coagulans as a coagulant on the quality and sensorial properties of tofu. African J. Food Sci. 8(3): $112-115$.

[15] Shih M.C, Hou, H.T. and Chang, K.C. (2006). Process optimization for soft tofu. J. Food Sci. 62: $833-837$.

[16] Gebre-Egziabher, A. and Sumner, A.K. (1983). Preparation of high protein curd from field peas. J. Food Sci., 8: 375 377,388 .

[17] Shokunbi, O.S., Babajide, O.O., Otaigbe, D.O. and Tayo, G.O. (2011). Effect of coagulants on the yield, nutrient and anti-nutrient composition of tofu. Applied Science Research, 3(3): $522-527$.

[18] AOAC (2010). Official methods of analysis. 18th (edn) Association of Official Analytical Chemists. Washington D.C.

[19] Sosulski, F.W., Garrat, M.O. and Slinkard, A.E. (1976). Functional properties of ten legume flours. Inst. Food Sci. Tech. J. 9:66- 69.

[20] Yatsumatsu, K., Sawada, K., Moritaka, S., Misalei, M., Toda,
J., Wada, T. and Ishii, K. (1972). Whipping and emulsifying properties of soybean products. Agric. Biol. Chem. 36: 719 $-727$.

[21] Sathe, S.K., Iyer, V and Salunkhe, D.K. (1981).Investigation of the great northern bean (Phaseolus vulgaris L.) starch: solubility, swelling, interaction with free fatty acids, and alkaline water retention capacity of blends with wheat flour. J. Food Sci. 46: 191 - 1917.

[22] Narayana, K. and Narasinga Rao, M.S. (1982). Functional properties of raw and heat processed winged bean (Psophocarpus tetragonolobus) flour. J. Food Sci. 42: $534-$ 538.

[23] Davis, O.C. and Goldsmith, P.C. (1977). Statistical Methods in Research andProductionPubl. For Chemical Industries Ltd by Longman Group Ltd, London

[24] Lu, J.Y., Carter, E. and Chung, N.A. (1980). Use of calcium salts for soybean curd preparation. J. Food Sci. 45: $32-36$.

[25] Holazo, M.A.F., Punzalan, E.J. and Gonzales, O.N. (1981). Development ofinstant soy tokua: effect of freezing and chemical treatments, Nutrisyon (Philippines), 6: $48-51$.

[26] Kinsella, J.E. (1976). Functional properties of protein: a survey. Crit Rev. Food Sci. Nutri. 7: 219 - 225

[27] Voutsinas, L.P., Cheung, E. and Nakai, S. (1983). Relationships of hydrophobicity to emulsifying properties of heat denatured proteins. J. Food Sci. 48: 26- 32.

[28] Horiuchi, T. and Fukushima, O. (1978). Studies on enzymemodified proteins as foaming agents: Effect of structure on foam stability, Food Chem. 3: 5- 42.

[29] Shimada, K. and Matsushita, S. (1980). Relationship between thermo-coagulation of proteins and amino acid compositions. J. Agric. Food Chem. 28(2): 13 - 17.

[30] Li-Chan, E., Nakai, S. and Wood, D.F. (1984). Hydrophobicity and solubility of meat proteins and their relationship to emulsifying properties. J. Food Sci. 9: $35-$ 350 .

[31] Kinsella, J.E. (1981). Functional properties of protein: Possible relationships between structure and function in foams. Food Chem. 7: 273 -288.

[32] Townsend, A. and Nakai, S. (1983). Relationship between hydrophobicity and foaming characteristics of food proteins. J. Food Sci. 8: 588 - 594.

[33] Eltayeb, A.R.S.M., Ali, A.O., Abuo-Arab, A.A. and AbuSalem, F.M. (2011). Chemical composition and functional properties of flour and protein isolate extracted from bambara groundnut (Vigna subterranean). Afri. J. Food Sci. 5(2): $82-90$ 